\title{
ISOLATING MECHANISMS AND MODALITIES OF SPECIATION IN THE JAERA ALBIFRONS SPECIES COMPLEX (CRUSTACEA, ISOPODA)
}

\author{
MICHEL SOLIGNAC
}

\begin{abstract}
Solignac, M. (Laboratoire de Biologie et Génétique Evolutives, C.N.R.S., 91190 Gif-surYvette, France) 1981. Isolating mechanisms and modalities of speciation in the Jaera albifrons species complex (Crustacea, Isopoda). Syst. Zool., 30:387-405.-Jaera albifrons is a complex of five intertidal species of Crustacea that are abundant on the cold and temperate coasts of the North Atlantic. Two or three species of Jaera albifrons occur frequently on the same strand, partially isolated (approximately 50\%) by ecological preferences. In zones of species overlap, hybrids remain scarce $(0.6 \%$ average); sexual isolation is due to homogamic tendencies of male sexual choice, to specific male displays and especially to female reactivity. Most of the $F_{2}$ recombinations are inviable; hybrid fitness, estimated from demographic data, is about 0.15 . Other isolating mechanisms (e.g. temporal, mechanical and gametic isolation) are missing. The study of variability of isolating mechanisms between pairs of species and populations and of incipient isolation within species allows formulating a plausible hypothesis on their origins. A geographical mode of speciation with establishment of sexual isolation and hybrid breakdown during geographic isolation is likely. [Modes of speciation; isolating mechanisms; sexual isolation; Crustacea; Jaera.]
\end{abstract}

Isolating mechanisms are factors which prevent or impede crosses between individuals belonging to different species or hinder the full success of hybrid progeny (Dobzhansky, 1937). The development of these mechanisms constitutes the essence of all speciation.

The mechanisms of cladogenesis can be studied experimentally at the species level in certain cases. One of the purposes of population genetics and evolutionary systematics is to study the characteristics of divergent populations and related species in order to trace the origins and reconstruct the history of evolutive discontinuities between them. This type of analysis was performed on the Jaera albifrons species complex (Crustacea, Isopoda, Asellota).

The albifrons complex is remarkably well suited to this type of investigation. It is composed of five closely related species (forsmani, praehirsuta, posthirsuta, ischiosetosa, albifrons); all are abundant along the North Atlantic coasts and easily bred in the laboratory. The species can be discriminated only by examination of male secondary sexual characters, females being morphologically in- distinguishable (Figs. 1 and 2). Although reproductively isolated in nature, these species offer outstanding possibilities for experimental hybridization.

A survey was made of the isolating mechanisms separating the species as well as an estimation of the relative importance of the various barriers between them. Information was obtained on their genetic determination and the variability between pairs of species and populations was investigated.

Field observations and experimental analysis of reproductive isolation allow formulation of hypotheses on the probable origin of isolating mechanisms and on the mode of speciation in the Jaera albifrons complex. In particular, they allow the definition of the mechanisms originally responsible for isolation between forms. They also bring out the similarities between the cladogenetic episodes which have led to the current species.

\section{ISOLATING MECHANISMS AND THEIR VARIATIONS}

The principal isolating mechanisms in species of the Jaera albifrons complex are ecological, ethological, and hybrid 

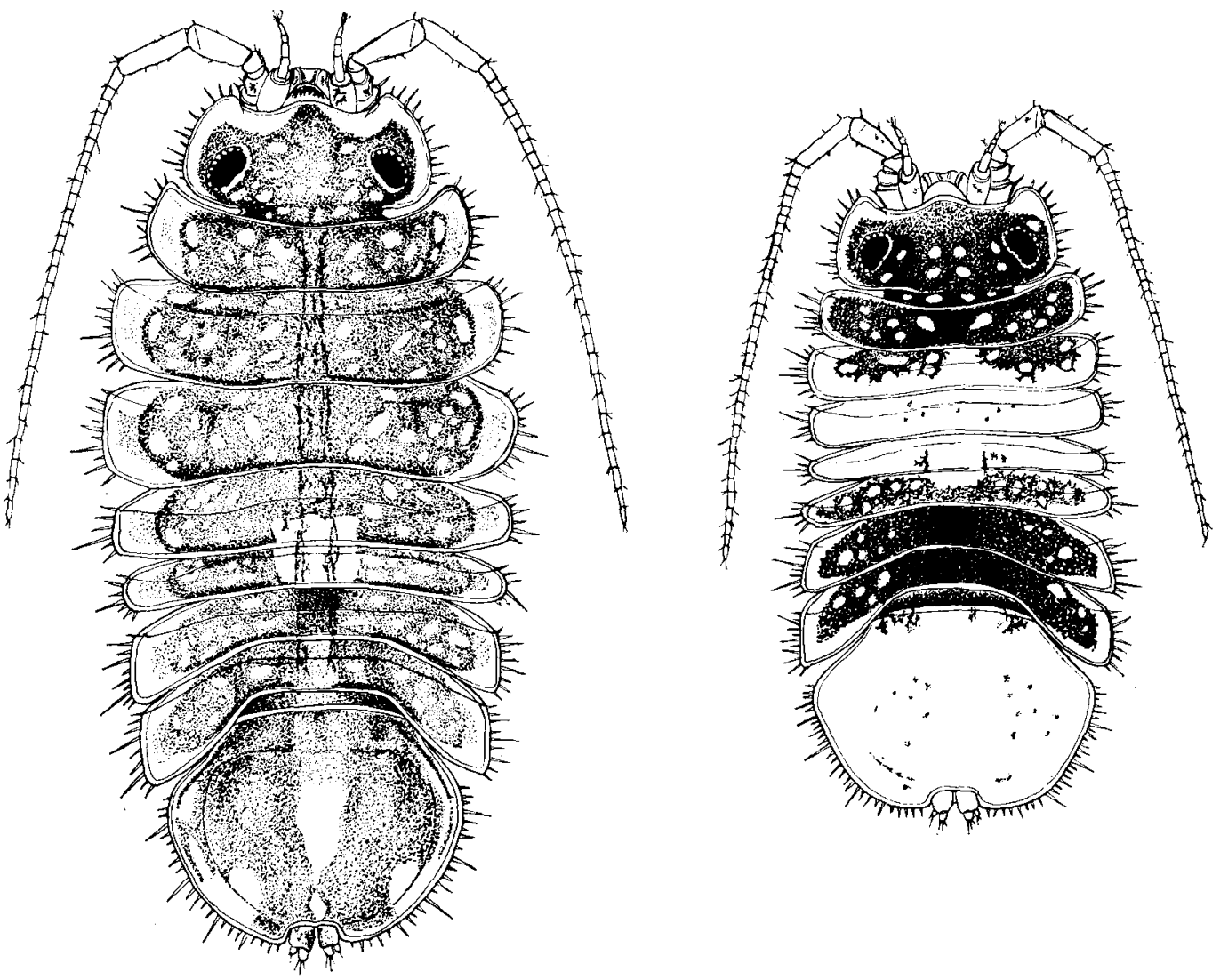

FIG. 1.-Habitus in Jaera (albifrons) ischiosetosa, Kiel population. The female, on the left, is a uniforme morph, the male, right, is Bifasciatum. The actual respective lengths are 3 and $2.2 \mathrm{~mm}$. This habitus is common, for both sexes, to all species from Jaera albifrons complex.

breakdown. Inviability of first generation hybrids was sometimes observed for one sex in one crossing direction.

Other isolating mechanisms seem to be completely absent or nearly so. There is neither temporal (Jones and Naylor, 1971), mechanical (Bocquet, 1953), gametic (Solignac, 1978a) isolation, nor hybrid sterility. Postnatal survival rates of interspecific hybrids, whatever their generation, is similar to that of pure parents.

Marked variability of isolation strength exists between the different pairs of species considered. However, within a given species pair, variability is also great depending on pairs of populations chosen to represent those species. Furthermore, incipient isolation can occur between populations within a species.

\section{Ecological Isolation and its Variation}

All five species of the albifrons complex are intertidal organisms of cold and temperate North Atlantic coasts. Jaera forsmani is restricted to the western coasts of Europe, whereas posthirsuta is exclusively American; albifrons, ischiosetosa and praehirsuta are distributed over an extensive geographical area on both sides of the Atlantic. The form syei, initially described by Bocquet (1953) as a distinct species, was later classified as an extreme morphological type of the species albifrons (Harvey and Naylor, 1967; Lécher, 1967; Prunus, 1968).

At certain sites, populations of Jaera albifrons are strictly monospecific. Con- 
A
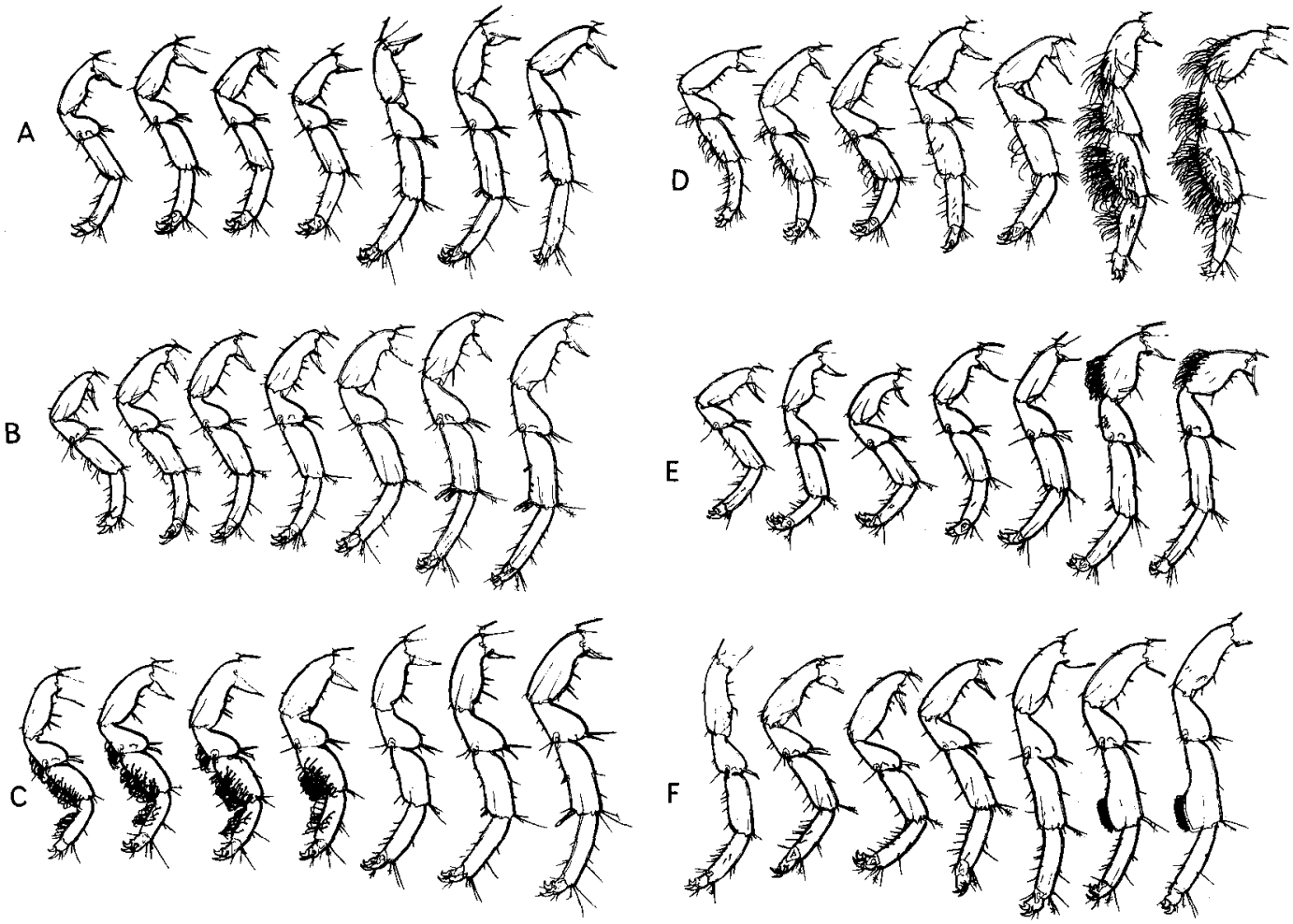

FIG. 2.-Pereiopods 1 to 7 (from left to right) in Jaera albifrons. A: female ischiosetosa (this thoracic leg morphology is common to females of all five species); B: male forsmani; C: male praehirsuta (form hirsuta); D: male posthirsuta; E: male ischiosetosa; F: male albifrons (form syei).

versely, two, three or four species of the complex are sometimes found on the same beach. Each species shows habitat preferences for tidal level, substrate (algae or stones), exposure to wave action and salinity range, which lead to some ecological isolation. Bocquet (1953) observed that species in Brittany were clearly zoned on the strand according to tidal level, and that specific distributions only overlapped along narrow contact bands. However, specific areas overlap widely in other regions (Pembrokeshire, Wales; Naylor and Haahtela, 1966); individuals of different species are interspersed under the same stones or on the same algae. In fact, a considerable local or regional variability of habitat isolation occurs: populations can be entirely monospecific, regularly zoned or intermingled.

\section{Sexual Isolation and its Variation}

In cases of natural sympatry or in experimental mixed populations, interspecific hybrids are exceptional, whereas hybrids can be easily obtained in the laboratory by suppression of partner choice (Bocquet, 1953; Solignac, 1976). Taking into account the absence of temporal, mechanical and gametic isolation and the viability of $F_{1}$ hybrids, ethological isolation appears fundamental in this complex as in many animal species.

In Jaera albifrons, the pair is formed on the male's initiative. Having mounted the female in a head-to-tail position, the male emits a highly specific stimulus-signal. The male stimulus consists in brushings, imposition of setae or spines, or pressures, performed on particular, 
species specific regions of the female tergites (Solignac, 1975). The nature of this stimulus is correlated in an extraordinarily precise way with the secondary sexual characters distinguishing each species (Fig. 2).

Virgin and impregnated females are frequently courted by males, but are rarely receptive. A single copulation ensures brood production every three weeks for several months. Non-receptive females exhibit strong reactions (pleotelson blows, shaking, quick runs).

Two main factors may determine sexual isolation between species: the choice of the female by the male (precopulation phase) and female reactivity to male overtures. The first factor was studied by the male choice technique; the second was analysed by no-choice hybridization.

Male sexual choice.-Equal numbers of females of two different species ( 20 of each) were introduced into a sea water tank. As females are morphologically indistinguishable, they were identified by genetic markers. These markers are Mendelian genes which determine an important polychromatism in natural populations; the description of the morphs (characterized by colour and distribution of body pigment) and their genetic determination was carried out by Bocquet (1953) and Cléret (1970).

Forty to fifty males belonging to the same species and population as one category of female were introduced in the experimental tank. As soon as a pair was formed, the two individuals were separated, the male was removed, and the female put back in the tank. After 20 minutes, most of the males had made a choice. Males of the second species were then tested in the same manner. For the two types of males, an isolation index (derived from Stalker's formula, 1942) was calculated as the difference between the number of homogamic and heterogamic choices, divided by the sum of the two.

Results can be reproduced with the same animals tested immediately after a first experiment or at intervals of one to several weeks, as well as with animals of different generations from the same strains (Solignac, 1978b).

Using the same procedure, experiments were performed on populations of different geographical origins within a species. Sexual choices between different morphs within populations were then analysed. A graphic representation is given in Figure 3 for intrapopulational, interpopulational intraspecific, and interspecific choices.

Within populations (Fig. 3A), sexual choices appeared to be random (points distributed near the origins) or selective, the two morphs of males being more attracted by the same female morph (one index is positive, the other negative with a similar absolute value). There is no indication of incipient isolation: the mean isolation index is $\overline{\mathbf{I}}=-0.01$.

Interpopulational experiments (Fig. 3B) provided a very different distribution of points: there is either no choice, a onesided choice (random distribution for one male, homogamy for the second), or bilateral homogamy. The mean isolation index for 26 experiments is $\overline{\mathrm{I}}=+0.20$ (i.e. $60 \%$ of homogamic choices). Index value is independent of the geographical distance separating the populations in nature (Solignac, 1978a). Homogamy is not

FIG. 3.-Graphical representation of intrapopulation (A), interpopulational intraspecific (B) and interspecific (C) male sexual choices. Isolation indices of male 1 and 2 are interchangeable; each value pair could be represented by two points which are symmetrical with respect to the first bisectrix. Only one is therefore plotted above this axis (dotted line). Symbols indicate species or species pairs ( $\mathbf{F}=$ forsmani, $\mathrm{Pr}=$ praehirsuta, $\mathrm{I}=$ ischiosetosa, $\mathrm{A}=$ albifrons, $\mathrm{Po}=$ posthirsuta $)$. Number of experiments is indicated to the left of the symbols. Average value of indices is shown below the symbols. For a more detailed discussion of this type of graph, see Solignac, $1978 \mathrm{~b}$. 

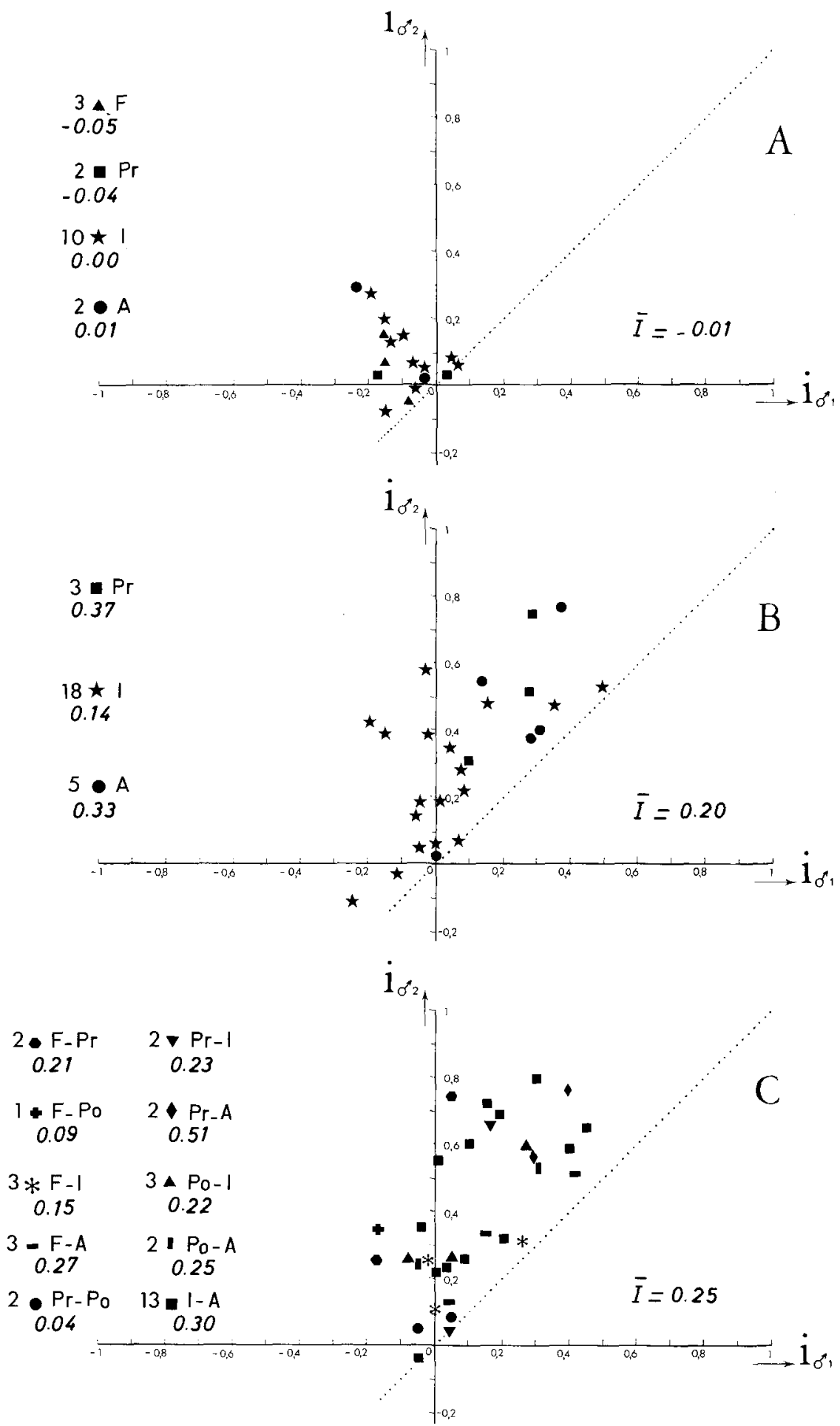

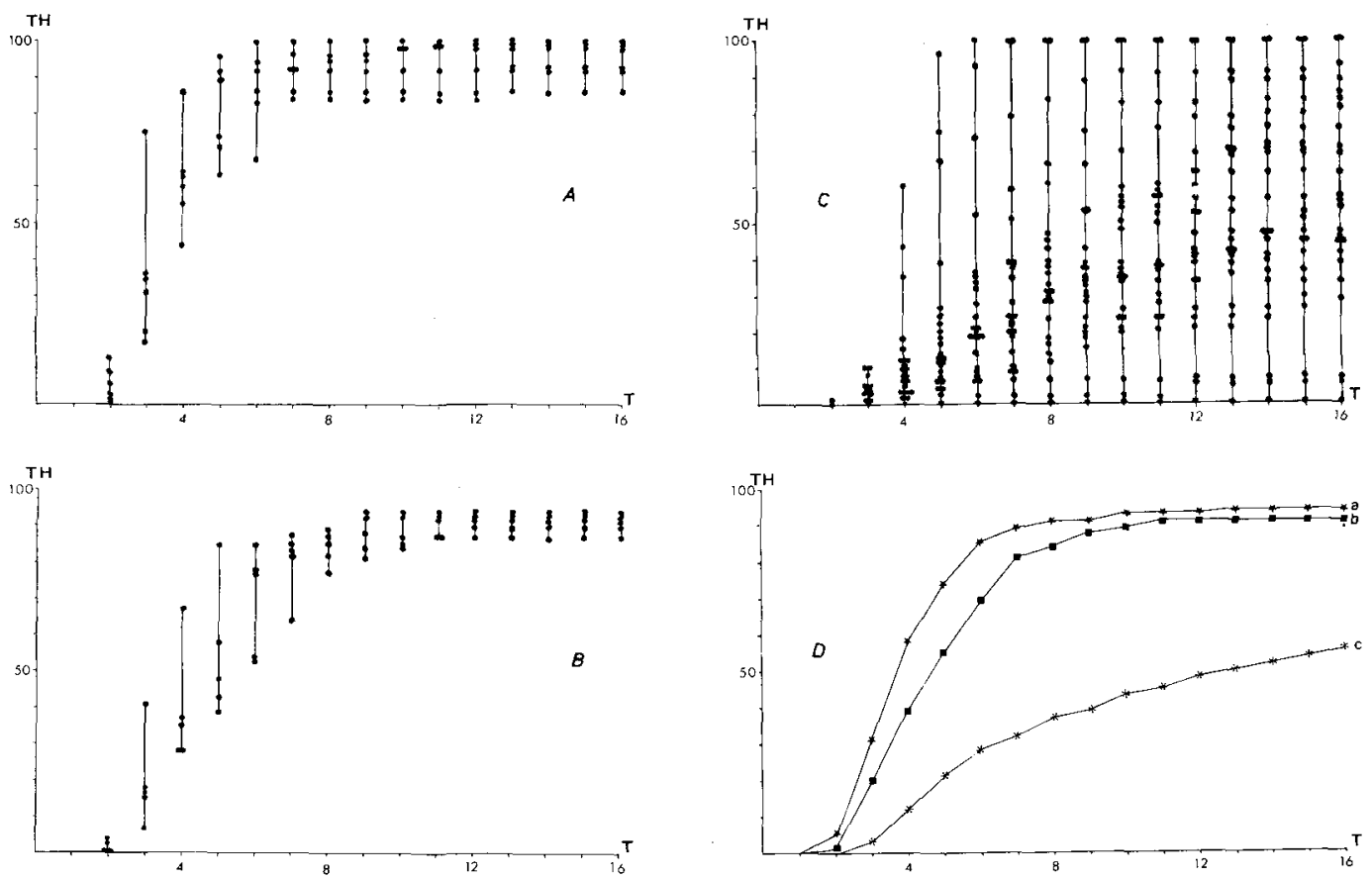

FIG. 4.-Evolution of the hybridization rate (TH, cumulated percentage of fertile pairs) as a function of time ( $T$, in weeks). A: intrapopulational references crossings ( 6 experiments). B: intraspecific interpopulational crossings (5 experiments) C: interspecific crossings (26 experiments) D: averages of previous distributions ( $\mathrm{a}, \mathrm{b}$ and $\mathrm{c}$ for $\mathrm{A}, \mathrm{B}$ and $\mathrm{C}$ respectively). In order to facilitate the reading of the figure, individual curves of hybridization were not drawn; all the curves should be regular as shown on diagram D.

directly correlated with genetic divergence, since genetic distance between populations increases with their geographic distance in nature (Cariou, 1977 and unpublished data).

Interspecific choices (Fig. 3C) were observed for the ten combinations of all five species considered by pairs. The results taken as a whole bring out the prevalence of homogamic choices, although the average isolation index $(\overline{\mathrm{I}}=+0.25)$ barely exceeds that of interpopulational choices. The number of tested populations varies greatly from one species pair to another, making comparisons difficult. Yet, for the species studied in greatest detail (i.e. albifrons and ischiosetosa) variability seems as great as for all of the other species pairs together.

A comparison between interpopulational and interspecific experiments re- veals that sexual choices depend more on the nature of the populations studied than on the nature of the species to which they belong. In both experiments, the genetic markers used for female identification have little effect on male choice (Solignac, 1978a).

When the choice of the partner is possible, females are courted slightly more by conspecific males than by alien ones. Male discrimination acts very early in the sexual display and prevents partners from wasting time in courtship without issue. However, it only accounts for a small part of ethological isolation.

Hybridization rates. - In experimental mixed populations, sexual isolation is as great as in nature. This barrier can only be overcome by forming isolated heterospecific pairs. For each experiment approximately fifty couples were constitut- 
TABLE 1. HybRidization RATES BeTWEEN SPECIES OF THE JAERA albiFRONS COMPLEX. INTRASPECIFIC REFERENCE CROSSINGS ARE SHOWN ON THE DIAGONAL.

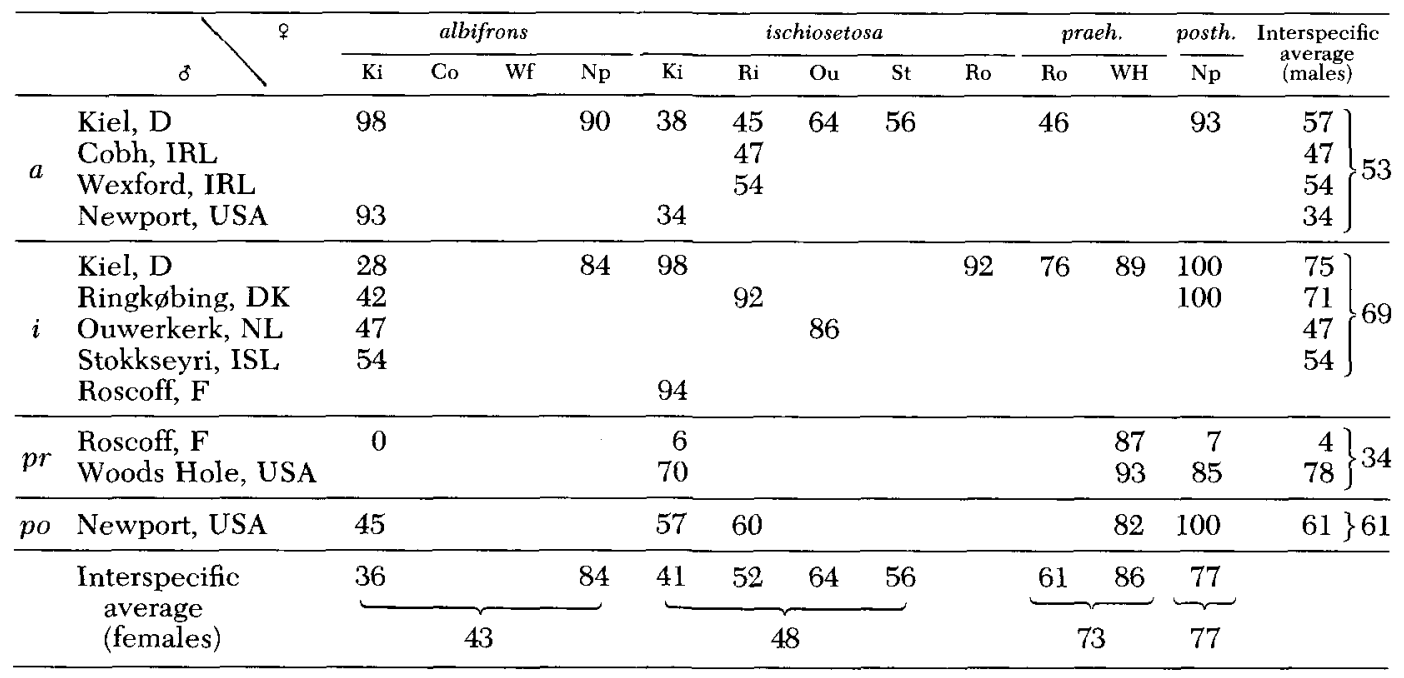

ed with virgin adults in both crossing directions and observed every week for four months.

Table 1 shows final crossbreeding rates and Figure 4 illustrates variability with time. Variation is amazing for different crossing combinations of four species considered in pairs (the fifth, forsmani, was not available at the time of experiments). Certain populations of different species show insemination rates as high as those of intraspecific reference crossbreeds, i.e. 90 to $100 \%$ of successful crosses after 4 to 5 weeks, whereas other pairs are almost impossible to cross, i.e. $0 \%$ or nearly so after a four month cohabitation. In most cases, results are intermediate between these extreme limits.
Males or females of a given species and population (lines or columns in Table 1) show hybridization rates which vary not only according to the species to which they are crossed, but also to the nature of the population. Such variation only has meaning provided that results can be reproduced for the same pair of populations used in interspecies crossbreeding. And indeed these results are reproducible (Solignac, 1978b).

Sexual isolation of hybrids.-One further aspect of ethological isolation concerns the sexual behavior of hybrids. First generation hybrids can be easily interbred or backcrossed with pure parents but they do not breed as rapidly as do intraspecific reference crossings. Four

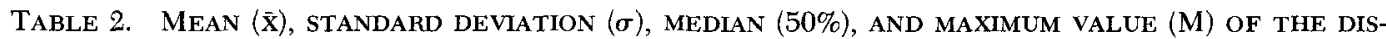
TRIBUTION OF LONGEVITIES (EXPRESSED IN WEEKS) OF FEMALE AND MALE JAERA (ALBIFRONS) ISCHIOSETOSA $(I), J$. (A.) ALbIFRoNS (A), AND F 1 RECIPROCAL HYBRIDS BETWEEN THESE TWO SPECIES, $A-I$ AND $I$-A.

\begin{tabular}{|c|c|c|c|c|c|c|c|c|c|c|}
\hline & \multicolumn{5}{|c|}{ Female survival } & \multicolumn{5}{|c|}{ Male survival } \\
\hline & $\overline{\mathbf{x}}$ & $\sigma$ & $50 \%$ & $\mathrm{M}$ & $\mathrm{Nq}$ & $\bar{x}$ & $\sigma$ & $50 \%$ & $\mathrm{M}$ & $\mathrm{No}$ \\
\hline$I$ & 19.75 & 8.84 & 21.00 & 35.50 & 144 & 33.20 & 14.68 & 32.67 & 58.63 & 106 \\
\hline$A$ & 20.30 & 9.02 & 21.79 & 38.50 & 129 & 33.19 & 13.09 & 32.80 & 58.25 & 116 \\
\hline$A-I$ & 23.40 & 12.08 & 24.18 & 54.50 & 147 & 32.84 & 17.00 & 35.72 & 69.50 & 156 \\
\hline$I-A$ & 19.85 & 10.29 & 22.00 & 39.50 & 42 & 33.25 & 14.42 & 34.00 & 64.50 & 152 \\
\hline
\end{tabular}


TABLE 3. AVERAGE NUMBER OF YOUNG PER BROOD IN THE 16 CROSSING TYPES BETWEEN ISCHIOSETOSA ( $I$, POPULATION FROM RINGK $\emptyset$ BING), ALBIFRONS (A, POPULATION FROM KIEL) AND THEIR RECIPROCAL F $F_{1}$ HYBRIDS (A-I AND $I$ - $A$ ). SEX-RATIO (N $\left.\$ / N{ }^{*}\right)$ IS INDICATED FOR PARENTAL CROSSES (REFERENCE AND HYBRIDIZATION).

\begin{tabular}{ccccc}
\hline${ }^{8}$ & & & & \\
\hline & $I$ & $A$ & $I-A$ & $A-I$ \\
\hline$I$ & 21.8 & 19.1 & 7.1 & 5.3 \\
& $(1.09)$ & $(0.95)$ & & \\
$A$ & 13.5 & 19.8 & 4.5 & 5.9 \\
& $(0.26)$ & $(1.07)$ & & \\
$I-A$ & 8.6 & 6.6 & 5.5 & 4.1 \\
A-I & 4.5 & 7.7 & 7.2 & 4.2 \\
\hline
\end{tabular}

generations of recurrent or non-recurrent backcrosses of hybrid females to pure males indicated that crossing success is positively correlated with the percent of genes shared by the male and the female (Solignac, 1978b, 1979). In the wild, where $F_{1}$ hybrids are generally too scarce to interbreed, only backcrosses have a reasonable probability of occurrence. The nature of the first backcross certainly conditions subsequent backcrosses which tend to be recurrent to the same species.

\section{Lethality of First Generation Hybrids}

The number of young per brood of pure females fertilized by alien males is usually identical or slightly lower than that of females of the same population in intraspecific crosses (Solignac, 1978a). However, in some crossbreeds, a noticeable deficiency of young was observed (see Table 3) associated with an abnormal sex-ratio (shortage of females, the heterogametic sex). This result was only obtained in $q$ ischiosetosa $\times \dot{\delta}$ albifrons crosses, not in the reciprocal crosses. It only appears with albifrons males originating from Kiel (German Baltic), whatever the population of ischiosetosa females may be. Intraspecific crosses with albifrons males from Kiel lead to offspring normal in quantity and in sex-ratio. The actual determination of the as-
TABle 4. Demographic PARAMETERS ESTABLISHED FOR THE TWO SPECIES JAERA (ALBIFRONS) ISCHIOSETOSA AND J. (A.) ALBIFRONS, AND FOR THEIR HYBRIDS. SURVIVAL DATA FOR HYBRIDS ARE THOSE OF FIRST GENERATION A-I FEMALES, FERTILITY DATA IS EXTRACTED FROM THE CROSS A-I $\times A-I\left(\mathrm{~F}_{2}\right.$ DESCENDANTS). INTRINSIC RATE OF NATURAL INCREASE: $r$; NET REPRODUCTION RATE: $\mathrm{R}_{0}$; DURATION OF ONE GENERATION: T; TIME NEEDED TO DOUBLE THE SIZE OF THE POPULATION: $t$. TIME IS EXPRESSED IN WEEKS.

\begin{tabular}{lcccc}
\hline & $\mathrm{r}$ & $\mathrm{R}_{\diamond}$ & $\mathrm{T}$ & $\mathrm{t}$ \\
\hline $\begin{array}{l}\text { ischiosetosa (Ringk } \phi \text { bing) } \\
\text { albifrons (Kiel) }\end{array}$ & 0.32 & 48.4 & 12.2 & 2.18 \\
$\begin{array}{l}\text { Hybrids A-I and their } \\
\quad \text { descendants of } \mathrm{F}_{2}\end{array}$ & 0.30 & 42.0 & 12.4 & 2.30 \\
\hline
\end{tabular}

sumed lethality of I-A hybrid females is not fully known. It quite probably involves female sex chromosomes $\left(W_{1} W_{2}\right)$ of ischiosetosa and autosomes of albifrons.

Postnatal survival rates have been determined (Solignac, 1976) for reciprocal interspecific hybrids between ischiosetosa (Ringkøbing population, Denmark) and albifrons (Kiel population, Germany). The postnatal viability of $I-A$ and A-I hybrids is, for both sexes, quite similar to that of pure $I$ and $A$ parents (Table 2).

\section{Hybrid Breakdown}

Most of the pairs formed with $F_{1}$ hybrids were found to produce offspring. All crossbreedings involving hybrids (including backcrosses) are less prolific, however, than crosses between pure parents (references and hybridizations). Most of the eggs laid degenerate in the mother's marsupium. Fecundity is about four times lower in the second generation (Table 3) and is not rapidly restored by repeated backcrosses to the same species. Based on experimental data of survival rates and fecundity, an estimation was made of hybrid demographic parameters compared to those of parents (Solignac, 1976). Table 4 shows that the mean number of female descendants left by each initial female $\left(R_{0}\right)$ is six to seven times lower. 
A particularity however occurs in the Jaera albifrons population from Luc-surMer (Normandy) which always exhibits a high percentage (15 to $30 \%$ ) of natural hybrids between albifrons and praehirsuta (Solignac, 1969, 1978a). Females already fertilized in their natural environment were collected and bred in the laboratory; those which produce hybrids (most of which are not $F_{1}$ ) seem to be as fertile as those which produce pure individuals. Though such an observation should be confirmed experimentally by controlled crossing, it seems that hybrid breakdown does not occur at sites where introgression takes place.

At all other stations, hybrid breakdown seems to be effective. It regularly occurred whenever studied experimentally, but as these experiments are extremely time consuming, there are not enough data yet for an evaluation of its variability.

RELATIVE IMPORTANCE OF THE VARIOUS ISOLATING MECHANISMS

When species live in monospecific populations or are clearly zoned, habitat isolation is fundamental. When individuals of different species are interspersed, the sexual barrier intervenes; when this fails, hybrid breakdown takes over. The factors responsible for reproductive isolation thus vary from one locality to another. However, it is interesting to estimate the respective weight of each isolating mechanism for the total geographic distribution of the complex.

The strength of ecological isolation is difficult to determine with precision: estimation accuracy depends on the way samples were collected and particularly on the extent of the area where each sample was drawn. Naylor and Haahtela (1966, 1967) have established, in this way, very precise microdistributions of species in Great Britain and the Baltic. Another example is given in Table 5 , based on samples taken by L. Schütz at various depths from twenty sites in the Nordostzee Kanal (linking the Elbe to the Baltic).

From the somewhat sparse published
TABLE 5. PERCENT OF STATIONS AND SAMPLES FROM THE NORDOSTZEE KANAL WHERE ONLY ONE OR TWO SPECIES WERE FOUND. PERCENT OF INDIVIDUALS FOUND IN SAMPLES CONTAINING EITHER ONE OR TWO SPECIES IS ALSO GIVEN.

\begin{tabular}{lccc}
\hline & $\begin{array}{c}\text { \% stations } \\
\text { (out of 20) }\end{array}$ & $\begin{array}{c}\text { \% samples } \\
\text { (out of 46) }\end{array}$ & $\begin{array}{c}\text { \% individuals } \\
\text { (out of 1197) }\end{array}$ \\
\hline Only 1 species & 55 & 61 & 40 \\
2 species & $\mathbf{4 5}$ & 39 & 60 \\
\hline
\end{tabular}

data (Jazdzewski, 1969; Naylor and Haahtela, 1966, 1967; Pethon, 1967; Sjöberg, 1969; Veuille, 1976) and from a personal communication ( $H$. Hoestlandt), it may be thought that $42 \%$ of Jaera albifrons stations or samples (out of a total amount of 297) include only one species, $39 \%$ include $2,18 \%$ include 3 and only $1 \%$ include 4 .

Consequently in the wild, $50 \%$ of the Jaera albifrons complex individuals (probably a minimum figure) are not found with individuals of other Jaera species. That is, due to their habitat selectivity and low vagility, they never meet individuals of another species of Jaera during their lifespans. Although partial segregation takes place through the ecological barrier, this factor in itself is insufficient to ensure an effective isolation of species.

In mixed natural populations, the low percentage of hybrids (usually ranging from $1 \%$ to $0.1 \%$, even sometimes zero) is a reliable indication of ethological isolation and of nothing else. As mentioned above, interspecific hybrids show an average survival in the laboratory which is comparable to that of pure parents. If females, already fertilized in a natural environment, are collected and brought to the laboratory, the natural proportion of hybridization can be estimated directly from the frequencies of interspecific hybrids appearing in the broods. The proportion of male hybrids observed in broods hatched in the laboratory is always similar to that of adult male hybrids found in stations where the females were collected. For example, samples taken by H. Hoestlandt on the East Coast of the 
United States during summer 1974 contained 6 hybrids among 774 adult males; only one female out of 229 produced interspecific hybrids in the laboratory. Comparable results were obtained several times for European populations. The scarcity of natural hybrids does not result from their disappearance (e.g., due to ecological inviability as suggested for other organisms by Anderson, 1949; Riley, 1952; Thoday, 1972), but from scarcity of hybridization. Although hybridization is reiterated every generation, hybrid breakdown prevents hybrid proliferation.

Of the ten combinations of interspecific hybrids, only nine are possible in nature (forsmani and posthirsuta being allopatric), of which eight are known. Only hybrids between forsmani and ischiosetosa have never been found. The frequency of natural hybrids was estimated from samples including two or three species. Eleven hybrids were detected (probably all $\mathrm{F}_{1}$ ) out of 1748 individuals, i.e. $0.6 \%$. Strength of sexual isolation can be estimated from the ratio of observed hybrid frequency and their calculated frequency if crossings occurred at random. As long as the number of individuals of the two mixed species are not extremely different-as was the case in studied samplings-a frequency of $0.6 \%$ of hybrids roughly corresponds to a sexual isolation of $98 \%$ to $99 \%$.

Of the several hundred stations studied in some detail, only three showed introgressive hybridization (Solignac, 1969, 1978a): Luc-sur-Mer (Normandy), where 15 to $30 \%$ of the population consists of hybrids between praehirsuta and albifrons; Sehestedt (Nordostzee Kanal) where samplings yielded 42 albifrons, 40 praehirsuta and 32 hybrids between praehirsuta and ischiosetosa (but no pure ischiosetosa!); and Concarneau (southern Brittany) where praehirsutaforsmani hybrids seem numerous (Cléret, personal communication).

If monospecific populations are considered (about $42 \%$ ), the proportion of interspecific hybrids for Jaera albifrons as a whole reaches about $0.3 \%$; perhaps $0.5 \%$ if populations with introgression are included.

Hybrid breakdown can be appraised from the demographic data of Table 4. An A-I female crossed with an A-I male leaves, on the average, six to seven times fewer descendants than a pure female. Fecundity of $A-I$ females is very similar when they are backcrossed to pure males. Taking these data into account, their estimated fitness is about 0.15 (1/6 to $1 / 7$ ). Fecundity only slightly increases during repeated backcrosses (Solignac, 1978a). Within a reproductive year (about three generations in a temperate climate), an initial pure albifrons female, for example, will have an average of $76,000 \mathrm{fe}$ male descendants $\left(\mathbf{R}_{0}+\mathbf{R}_{0}{ }^{2}+\mathbf{R}_{0}{ }^{3}\right)$, whereas a hybrid female will produce only 400 . Thus, in the event of a failure in the sexual barrier, hybrid breakdown acts as an effective interspecific barrier, even though hybrids and backcrosses of various generations can be obtained in large numbers in experimental conditions.

\section{ORIGIN OF ISOLATING MECHANISMS}

Before discussing the possible modalities of speciation, the processes of divergence that allow the establishment of interspecific barriers should be considered. Several preliminary questions can be useful in specifying the nature of the problem. First, all five current species of the Jaera albifrons complex are derived from an "ancestral Jaera albifrons" (Bocquet, 1953) resulting from four episodes of cladogenesis. Has each of these speciation events taken place according to the same mechanism, or does each display species specific features? Second, the current species are a result of the split of a single ancestral form which very likely differentiated into a number of populations or subspecies, certain characteristics of which may have endured. During the process of speciation (allopatric phase of Mayr, 1942; phase one of Ayala et al., 1974; Lewontin, 1974; 
White, 1978a), further distinctions appeared; the most important being those which can restrict severely the possibility of gene exchange. These new species, originating at a particular site, district, or region overran other territories and underwent geographic diversification (occasionally with a reinforcement, Dobzhansky, 1937; corresponding to phase two of authors quoted above). The observed differences are the sum of those which preceded, accompanied and followed speciation. Third, all of the isolating mechanisms are not equally effective. Some are essential, others are weak, accessory, or accidental. Were the strongest barriers established at the time of speciation and the others later on? When a single isolating mechanism exists between two species, speciation coincides with the establishment of that barrier. When there are many mechanisms, as in Jaera, one may wonder whether only one, several, or all originated during cladogenesis.

A study of interspecific and interpopulational variability may help us to answer some of these questions. Using the data currently available on Jaera, plausible hypotheses can be suggested. In particular, based on the diversity, variability, and importance of isolating mechanisms, it is possible to illustrate that very different processes were involved in their establishment.

\section{Male Sexual Choice}

The existence of incipient isolation between populations within species could indicate that this factor has contributed to past cladogenetic episodes, and could eventually contribute to future ones. No trace, however, has been found. We have seen that on the average males of a given population discriminate against females of another population from the same species as much as against females of other species. Male discriminative capacities display the same variability in interpopulation and interspecific choices. This variability seems to be random; it is not due to reinforcement (Solignac, 1978a) and does not depend on the geographic (and genetic) distance between populations.

A permanent coordination of sexual stimuli and responses between males and females is necessarily preserved in each population. Within a species, homogamy appeared as a by-product of intersexual coadaptation within populations and of geographic variation. Incipient isolation between species results from the superimposition of independent intraspecific variations.

\section{Sexual Variants and Male Sexual Behavior}

Despite some minor variation in these parameters, male morphological and ethological characters remain homogeneous and distinctive from a qualitative point of view in all populations of a species (except praehirsuta and forsmani). The fine structure of setae and spines and their precise localization on parts of appendages preclude multiple and independent appearance of these specific characters (Fig. 2). Their differentiation must be interpreted as a single event which occurred during the emergence of the species. Sexual behavior, which is highly correlated with the nature of male secondary sexual characters, probably differentiated simultaneously.

\section{Female Reactivity.}

When partner choice exists, females are almost always impregnated by conspecific males in spite of frequent errors in male choice. Female receptivity then remains between a minimum threshold allowing reproduction and a maximum threshold above which hybridization could occur. The artificial suppression of partner choice probably indicates the heterogeneity of female reactivity within these limits. However, other factors intervene since hybridization rate of females depends on the species and population of males to which they are crossed. The lack of negative correlation between 
the results obtained with males and females of the same population precludes the simple effect of differential levels of female receptivity and male solicitation (Solignac, 1979).

Compared to the constancy of isolation in the case of mating choice, the variability of the results obtained in nochoice experimental hybridizations is difficult to interpret. Therefore, a precise determination of the moment when that fundamental barrier was established cannot be made.

\section{Lethality of I-A $F_{1}$ Hybrid Females}

The lethality of $F_{1}$ hybrid females was only observed in the crosses $q$ ischiosetosa (from all populations) $\times \hat{\delta}$ albifrons (population of Kiel exclusively). It was not observed in interpopulational crosses within each species. Therefore, whatever the precise genetic or cytogenetic mechanism determining this lethality of $I-A F_{1}$ females, it can be interpreted as a result of the joint effect of two factors. One factor, present in female ischiosetosa, is common to all populations of that species and absent in other species. It was probably established at the time of speciation, during separation from albifrons (Fig. 7). Thus ischiosetosa possessed a characteristic which "potentially" isolated it from albifrons. The other factor is only present in Kiel albifrons and can be considered as a postspeciational geographic differentiation. The divergence thus appeared at different moments of the evolutionary history of the two species, but can be compared with Dobzhansky's model (1970:375-376) on complementary genes at two loci.

\section{Hybrid Breakdown}

Data on hybrid breakdown are too fragmentary to allow definite conclusions, but they seem homogeneous. This type of isolation could have developed during an early phase of the speciation process. It could also have developed when species, already in contact, were protected by a sexual barrier. Divergence oc- curring within each species, although ineffective in intraspecific crosses, may acquire the value of an isolating mechanism in interspecific crosses. Their determination can be genetic, but also chromosomal, and correlated with the many Robertsonian alterations detected between and within species of the Jaera albifrons complex (Staiger and Bocquet, 1956; Lécher, 1967; Lécher and Solignac, 1975). In various species, homologous limbs could be involved in different fusions, leading to difficulties at meiosis as in Mus musculus (Cappana et al., in White, 1978b). Variability of this kind of isolation is still not well-known in Jaera. Additional experimental data are needed as well as a study of meiosis in interspecific hybrids to allow tracing its genesis in a more precise way.

The lack of this barrier between praehirsuta and albifrons from certain sites in Normandy (observations still need to be confirmed experimentally) is probably secondary. Introgressive hybridization was first detected in this population more than 20 years ago (about 100 generations) and probably existed prior to this. At any rate, it has continued since then. The equilibrium maintained between hybrids and parents is rather enigmatic, since hybridization seems to have eliminated genes or chromosome arrangements which determine the breakdown.

\section{The praehirsuta-forsmani Relationship}

These are undoubtedly the most closely related species within the albifrons complex (morphology: Bocquet, 1953 and Fig. 2; sexual behavior: Solignac, 1975; genetic distance: Cariou, 1977 and Fig. 7). They are separated morphologically only by quantitative differences. In western France praehirsuta (represented by the form hirsuta - a morphological extreme type of the species), can easily be distinguished from sympatric forsmani. From Normandy to Boulonnais (Channel), there is only one form (paucahirsuta) which is intermediate in many respects (size and morphology, Fig. 5; and 

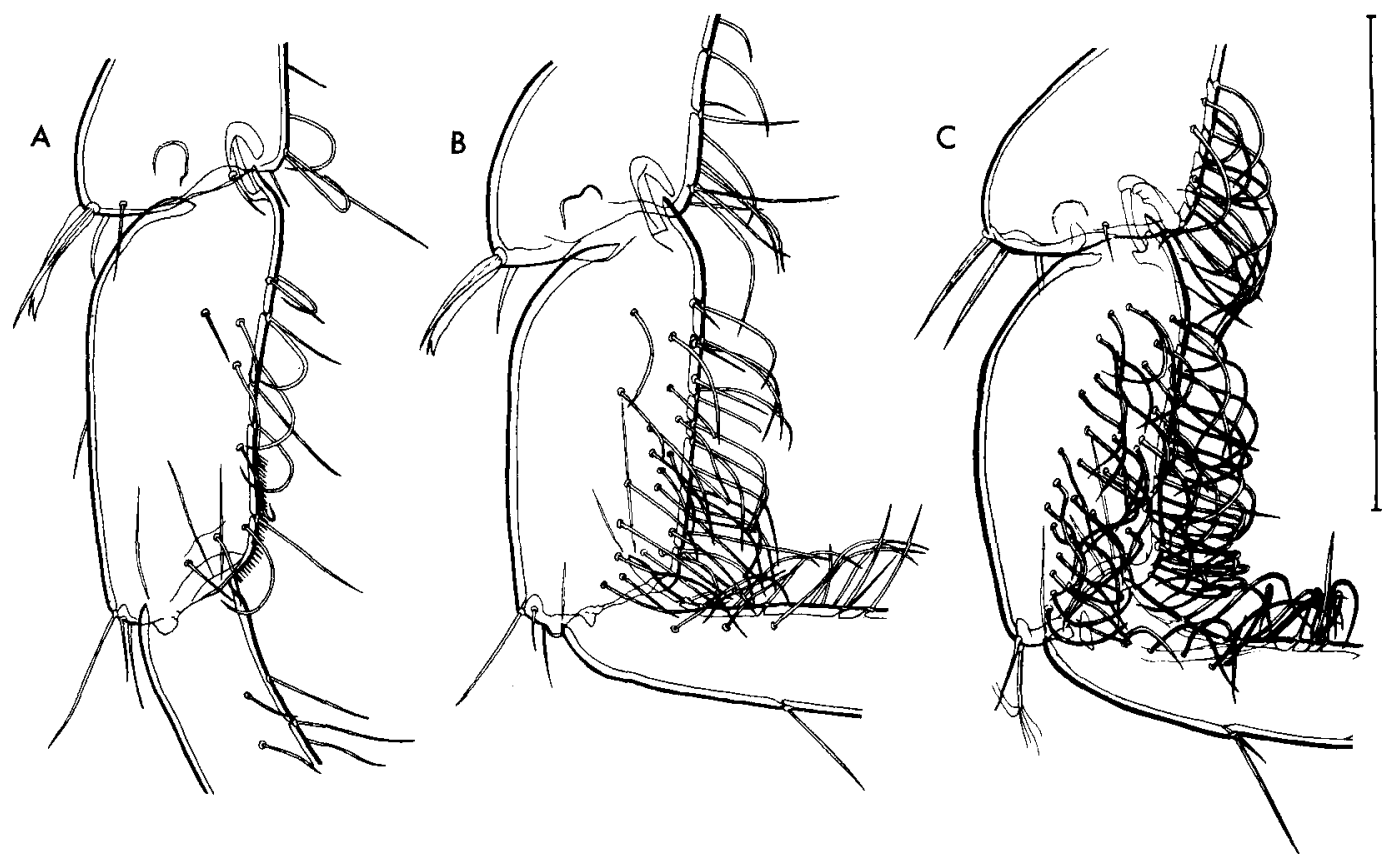

FIG. 5.-Comparison of setosity of pereiopods $1\left(\mathrm{P}_{2}\right.$ for $\left.\mathrm{C}\right)$ carpopodites in male Jaera albifrons. A: forsmani, Anse Saint-Martin (2.58 mm). B: praehirsuta, form paucahirsuta, Sainte-Honorine-des-Pertes (2.46 mm). C: praehirsuta, form hirsuta, Roscoff Penzé $(2.06 \mathrm{~mm})$. A and C come from the region of sympatry between praehirsuta and forsmani. B is the typical form of the northern coasts of France where praehirsuta occurs without forsmani. The line which indicates scale represents $0.2 \mathrm{~mm}$.

ecology) between hirsuta and forsmani. Biogeographical and biometrical studies support the assignment of paucahirsuta to praehirsuta (Solignac, 1967; discriminant analysis in progress). American populations of praehirsuta seem both highly variable and very different from European populations.

Evolutionary relationship between forsmani and the diverse forms of praehirsuta are complex and could be the result of a set of numerous factors and processes: achieved speciation (forsmani-praehirsuta); persistence of ancestral forms (paucahirsuta); long geographic isolation (American and European populations of praehirsuta); character displacement (Brown and Wilson, 1956) in sympatric forsmani and praehirsuta; and, perhaps for some cases, undetected hybridization.

The diversity of the processes by which isolating mechanisms can be established is quite striking. Nevertheless, in tracing speciation in Jaera albifrons, the only mechanisms to be considered are those which appeared at the time of cladogenesis, whereas those which more recently developed during subsequent phyletic evolution (including geographical differentiation) are not relevant to the process of speciation itself. Among the former, we must take into account only those which were strong enough from the beginning to interrupt or sufficiently curb the gene flow.

\section{MODALITIES OF SPECIATION IN \\ THE JAERA ALBIFRONS COMPLEX}

Bocquet (1953, 1954) had considered three models of speciation in Jaera albifrons: one strictly geographical; one ecological; and the third is a composite of these. Bocquet was impressed by the strict zoning of species whose distribution areas near Roscoff, Brittany, where his work was carried, overlap only on nar- 
row contact bands. It seems now that such a situation is too rare to support a primarily ecological mode of speciation.

However, speciation of Jaera becomes meaningful only if the ecological aspect is taken into account. Ecological particularities may have been fixed at the time of the origin of each species, but the ecological barrier is too weak to have acted as the primary factor in the speciation process. The split of the ancestral form into several species has allowed differentiations, specializations, and certainly ecological conquests in the intertidal zone where microhabitats are better utilized by a complex of species than by a single species.

Each species of the albifrons complex occupies several to many meters of strand width; the species are in mutual contact over about fifty thousand kilometres of coastlines. Each was differentiated within a restricted area whose particularities (e.g., ecological, climatic factors, and relations with other populations) cannot be inferred by observing only the current ecogeographical status. Thus, the present distribution of species (zoned rather than parapatric) is not very helpful in establishing a model of speciation for Jaera albifrons.

The role of chromosomal structural changes (fusion or fission) as primary factors of stasipatric speciation in Jaera was discussed by Bocquet (1969) and White (1978a). In the Jaera albifrons complex, Robertsonian rearrangements explain intrapopulation polymorphisms, intraspecific geographical variation, and interspecific differences. Within the albifrons species (including the syei form), the diploid number varies geographically according to a cline along the western European coastline (Lécher, 1964). Distributions of different diploid numbers are parapatric. Contacts between two different symmetrical formulae occur in small zones ("tension zones," Key, 1968) showing a deficiency of heterozygotes. Experimental hybrids between populations that differ by a single fusion show a regular meiosis; sometimes with an univa- lent element. Meiotic abnormalities are more severe in structural heterozygotes whose parents differed by several centric fusions: partial asynapsis, association between non-homologues (Lécher, 1967). Single centric fusion can perhaps restrain the gene flow between contiguous populations, but the attainment of a sufficient level of isolation would require several fusions, or better still, differential fusion. That is, fusion of homologous limbs with heterologous limbs. The kind of parapatric differentiation seen in albifrons was probably unable, in itself, to bring about speciation.

The intensity of interspecific barriers suggests that the "point-of-no-return" (Bush, 1975) has been surpassed, just barely. Thus, most of the differences became fixed during speciation. Considering their nature, variability, and multifactorial determination, it is hard to explain how such differences could have become fixed in the presence of pronounced gene flow. In other words, geographic speciation (Mayr, 1942) is highly probable, even though accessory isolation may have developed through reinforcement or as a by-product of phyletic change subsequent to speciation.

If one assumes geographical speciation, then one can attempt to define a more precise chronology of barrier fixation. According to the existing isolating mechanisms and their strengths, three hypotheses can be proposed. Two are "minimalist" and the third is "maximalist." The uncertainty obviously comes from the difficulty encountered in specifying the origin of the two main isolating mechanisms; female reactivity and hybrid breakdown.

1. According to a purely ethological hypothesis, differences developed during geographical isolation affect male secondary sexual characters and behavior. Female reactivity was simultaneously modified, together with male morphological and ethological characteristics. The sexual displays of males from the divergent population became ineffective in 
eliciting receptivity from females of other populations. The differences fixed in this way as by-products of sexual adaptation within populations acted as isolating factors between populations. The genetic basis of hybrid breakdown developed later, as the populations from different species, protected by sexual isolation, accumulated genetic or chromosomal differences entailing major imbalances in $\mathrm{F}_{2}$ recombinations. ${ }^{1}$ Nevertheless, at the initial meeting of the "new species," hybridization would certainly have taken place, at least as intensive as the present $0.6 \%$ rate. The problem is that we do not know whether, in the absence of hybrid breakdown at the very onset of the contact, such a gene flow could have been tolerated without jeopardizing the efficiency of that isolation.

2. A second hypothesis consists in assuming fixation of hybrid breakdown during "geographical isolation."1 A divergence of male secondary sexual characteristics could also have developed during that phase. Prezygotic (sexual) isolation, based on morphological divergence, would however have only become effective by subsequent development of female reactivity in the zones of sympatry. In fact, ethological barrier can be selected for itself, insofar as it prevents the production of disadvantaged hybrids, as the individuals exhibiting homogamous trends leave more descendants than those which hybridize. This reinforcement of isolation would essentially have affected female reactivity.

3. All of the essential isolating mechanisms (ethological isolation and hybrid

\footnotetext{
${ }^{1}$ Whether hybrid breakdown developed under the protection of sexual isolation (first hypothesis) or during the allopatric phase (second hypothesis), isolation could only result from independent divergence occurring in each population. Gene or chromosome modifications which control this hybrid breakdown are enhanced by evolutionary forces which, when they are acting, are independent of this effect. Like other postzygotic mechanisms, hybrid breakdown cannot be selected for itself.
}

breakdown) may have developed during the phase of geographical isolation of the populations as a by-product of adaptative or non-adaptative divergence and of male-female coadaptations. Species originating in this way would then have possessed, from the beginning, the main isolating mechanisms we now detect.

These hypotheses can be compared to a model (Fig. 6) designed by Bossert (1963) and presented by Wilson (1965). Perhaps all of the requirements for application of this model are not completely fulfilled in Jaera, but, according to Wilson, the model is robust and the results can tolerate, fairly well, an easing of one condition. This model has not been tested in nature or in the laboratory and cannot therefore constitute proof; only an approach. However, it is more realistic than many others for parameters that can be evaluated (Udovic, 1980), and takes into account the two main isolating mechanisms detected in the Jaera albifrons complex. Each of the three hypotheses is plotted in Figure 6. Data on hybridization (initial error) were obtained in the wild, whereas those on hybrid breakdown (heterozygote fitness) were obtained in the laboratory. Nevertheless, the latter is not subject to significant variation between artificial and natural conditions. Rubinoff and Rubinoff (1971) also referred to this model in their study of the fish genus Bathygobius using experimental hybridization rates as an estimation of initial error.

With the first hypothesis (a 1\% crossbreeding rate and a fitness of hybrids equal to 1), the outcome is uncertain between fusion and separation of the two populations; although the tendency is toward fusion. According to the second hypothesis, if random crossing takes place between two equally abundant parental populations, the hybridization rate is $50 \%$ and the hybrid fitness is 0.15 , indicating a probable fusion. To enter the "probable separation" zone, both isolations should act simultaneously, in accordance with the third hypothesis. 


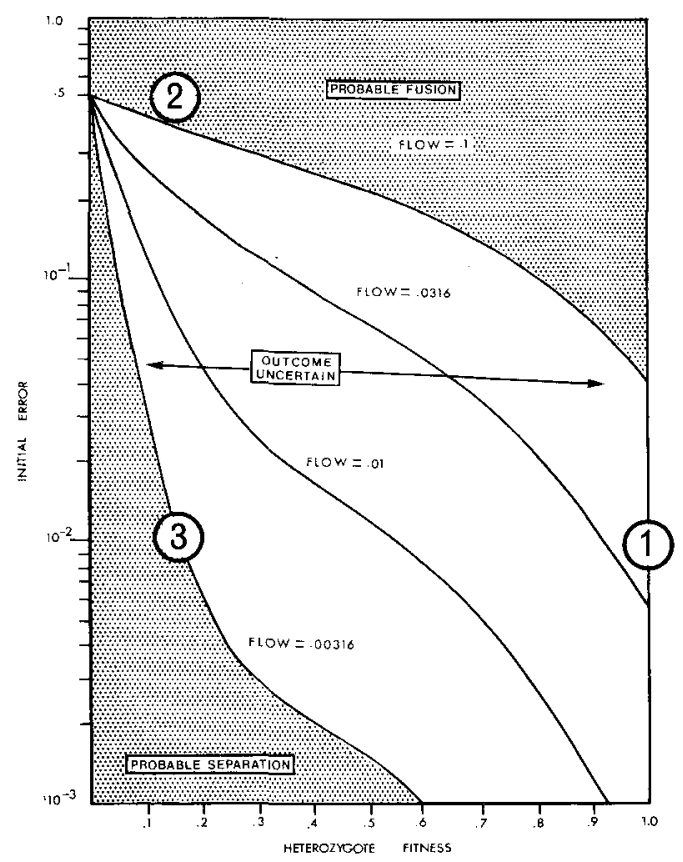

FIG. 6.-Prediction of the result of contact between populations showing various degrees of reproductive isolation. The mean rate of gene flow for the first 50 generations following the beginning of the sympatry is given as a function of the initial crossing error and hybrid fitness. From Wilson, 1965. The circled numbers correspond to the three hypotheses described in the text.

The current species are in position 3 of course, and the fact that they remain isolated is in agreement with the predictions shown on the graph. Nonetheless, it is possible that a lower sexual barrier or hybrid breakdown (or both) could be sufficient to maintain species isolation. However, with the possible exception of some weak or accidental mechanisms, it is likely that the two main barriers observed between species were established during the process of speciation and depend very little on subsequent phyletic evolution.

The capacity for hybridization in the Jaera albifrons complex could argue in support of a recent origin of species; although, the loss of this capacity evolves at strikingly different speeds among other zoological classes (Wilson et al., 1974;
Prager and Wilson, 1975) and is unknown in Crustacea. In fact, the genetic distance between Jaera species (Cariou, 1977; Fig. 7) suggests that differentiation occurred during the last two million years. The Pleistocene epoch indeed appears highly suitable to the speciation of these organisms, considering the innumerable changes in climate, accompanied by fluctuations in sea level and salinity. The individualization of the ancestral Jaera albifrons from the other species of the genus is probably far more ancient, dating from the drying of the Mediterranean, 15 million years B.P. (Veuille, 1979).

\section{CONCLUSIONS}

White (1978a) has drawn up the "ideal" store of knowledge required to establish a speciation model involving little risk of error. Although the knowledge now acquired on Jaera includes a number of his items, it does not cover all of them in complete detail. It should be pointed out that studying the variation of isolation between species and populations was, in addition to White's list, the most useful method for the analysis of speciation.

All five species of the Jaera albifrons complex result from four episodes of cladogenesis; each speciation, of course, was an independent event, but all have acted, nevertheless, on the same characters. It is interesting to note that speciation always affected the morphology of male pereiopods and relevant behavior, as well as hybrid breakdown. Such parallelism in the process of speciation, though far from general, is not rare (e.g., male sterility in Drosophila and other dipterans; ecological specialization of monophagous insects; "chromosomal speciation" in Morabinae and rodents). It clearly indicates the existence of similar trends in variation or selection in some related species.

One further point concerns the relationship between phylogeny and sexual isolation (hybrid breakdown is still not well enough known for discussion). Although the degree of sexual isolation is 


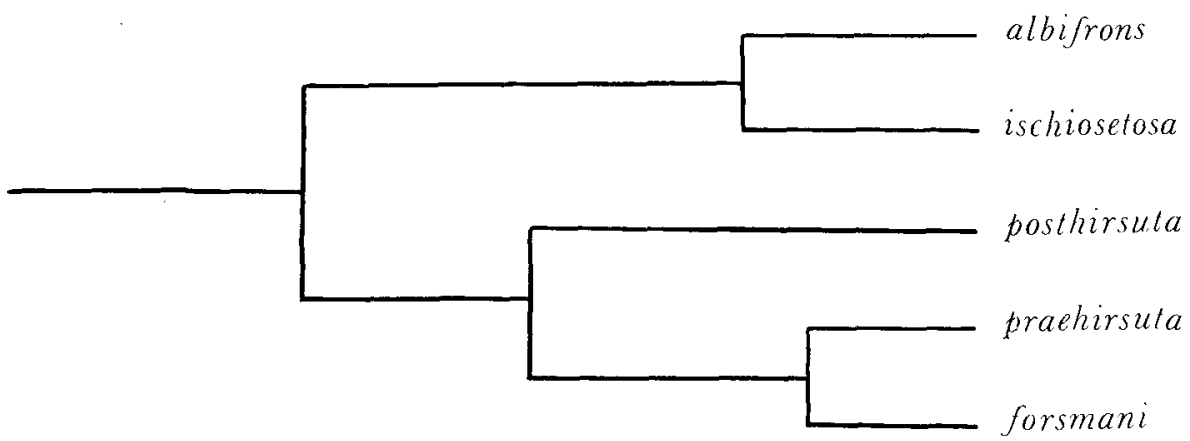
forsmani

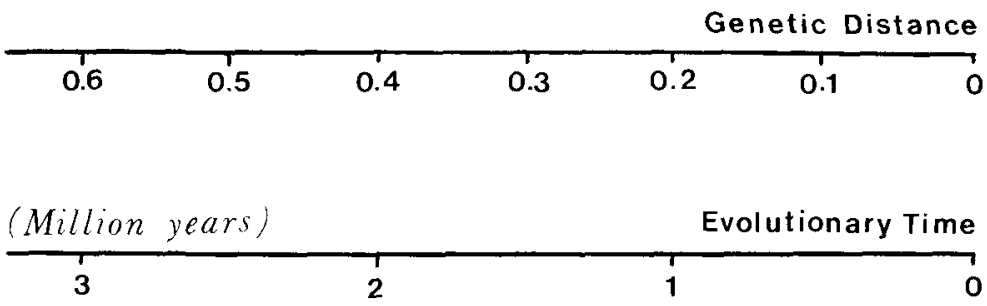

FIG. 7.-Presumed phylogeny of the five species of the Jaera albifrons species complex. Genetic distance was calculated according to Nei's formula (1975) on the basis of allelic frequencies at eleven loci in seventeen populations (from Cariou, 1977 and 1979). Additional loci and other populations are still under study.

certainly somewhat related to phylogeny, some risks exist in using results of ethological isolation for phylogenetic reconstitution. This method was used for example in the study of several groups of species in the genus Drosophila, with opposite conclusions, by Kaneshiro (1976) and Watanabe and Kawanishi (1979). In Jaera albifrons, the variability of sexual isolation (male choice and rates of hybridization) observed between pairs of species is certainly an inappropriate estimation of phyletic relationships (Solignac, 1979). In fact, it is deprived of a large part of its meaning by the heterogeneity observed when different populations were used to represent species pairs in tests of sexual isolation. In addition, the degree of sexual isolation does not agree, even approximately, with the probable chronology of divergence established through the study of enzymatic variants (Fig. 7, after Cariou, 1977, 1979). Sexual isolation seems independent not only of the length of anagenetic segments (phyletic evolution) connecting the species, but also of the number of cladogeneses lying between them; this number is perhaps greater if some species are now extinct. In other words, in the Jaera albifrons complex, the species are still just above the threshold of "probable separation," whatever their age, and the disruptive processes are not of an additive nature.

\section{ACKNOWLEDGMENTS}

The author is particularly grateful to Prof. E. Mayr, M. Lamotte, and J. Génermont for constructive criticisms and helpful comments on the text. Special thanks are given to Leslie Wheeler who corrected the English language of the last version.

\section{REFERENCES}

ANDERSON, E. 1949. Introgressive Hybridization. John Wiley and Sons, New York, 109 pp.

Ayal. F. J., M. L. Tracey, D. Hedgecock, AND R. C. RICHMOND, 1974. Genetic differentiation during the speciation process in Drosophila. Evolution, 28:576-592.

BoCqueT, C. 1953. Recherches sur le polymor- 
phisme naturel des Jaera marina (Fabr.) (Isopodes Asellotes). Essai de Systématique Evolutive. Arch. Zool. exp. gén., 90:187-450.

BoCQUET, C. 1954. Evolution of a superspecies of Isopods. Syst. Zool., 3:148-162.

BocQuer, C. 1969. Le problème des formes apparentées à distribution contiguë. Bull. Soc. Zool. France, 94:517-526.

BOSSERT, W. H. 1963. Simulation of character displacement in animals. Ph.D. dissertation, Harvard University, Division of Engineering and Applied Mathematics.

Brown, W. L., AND E. O. Wilson. 1956. Character displacement. Syst. Zool., 5:49-64.

Bush, G. L. 1975. Modes of animal speciation. Ann. Rev. Ecol. Syst., 6:339-364.

Cariou, M. L. 1977. Recherches sur le polymorphisme enzymatique du complexe Jaera albifrons, Leach (Crustacé, Isopode). Thèse, Université de Paris VI., $76+73 \mathrm{pp}$.

Cariou, M. L. 1979. Polymorphisme enzymatique et relations phylogénétiques des espèces du complexe Jaera albifrons (Crustacés, Isopodes). Bull. Off. natn. Pêch. Tunisie, 3:55-58.

Clenet, J. J. 1970. La pigmentation de Jaera albifrons Leach. V. Equilibre du système pigmentaire et gènes responsables du polychromatisme. Arch. Zool. exp. gén., 111:447-493.

Dobzhansky, TH. 1937. Genetics and the origin of species. (1st ed.). Columbia Univ. Press, New York, 346 pp.

Dobzhansky, TH. 1970. Genetics of the Evolutionary Process. Columbia Univ. Press, New York and London, 505 pp.

Harvey, C. E., and E. Naylor. 1967. The taxonomic status of Jaera albifrons syei Bocquet (Isopoda, Asellota). Crustaceana, 14:185-193.

JAZDZEWSKI, K. 1969. Ecology and biology of species of the Jaera albifrons group (Isopoda, Asellota) in the Bay of Puck, Polish Baltic Sea. Crustaceana, 17:265-281.

JoNES, M. B., AND E. NAYLoR. 1971. Breeding and bionomics of the British members of the Jaera albifrons Leach group of species (Isopoda Asellota). J. Zool. London, 165:183-199.

KANESHIRO, K. Y. 1976. Ethological isolation and phylogeny in the planitibia subgroup of Hawaiian Drosophila. Evolution, 30:740-745.

KEY, K. H. L. 1968. The concept of stasipatric speciation. Syst. Zool., 17:14-22.

LECHER, P. 1964. Recherches complémentaires sur le polytypisme de la super-espèce Jaera albifrons Leach (=Jaera marina Fabricius). III. Etude chromosomique de différentes populations de Jaera albifrons syei Bocquet. Bull. Biol. Fr. Belg., 98:415-431.

LECHER, P. 1967. Cytogénétique du polymorphisme chromosomique robertsonien chez l'Isopode Jaera (albifrons) syei Bocquet. Arch. Zool. exp. gén., 108:633-698.

LECHER, P., AND M. SOLIGNAC. 1975. Etude caryologique de Jaera (albifrons) ischiosetosa (Crustacés, Isopodes). III. Cline chromosomique des côtes ouest européennes. Arch. Zool. exp. gén., $116: 591-614$.

LEwontin, R. C. 1974. The Genetic Basis of Evolutionary Change. Columbia Univ. Press, New York, 346 pp.

MAYR, E. 1942. Systematics and the Origin of Species. Columbia Univ. Press, New York, 334 pp.

NAYlor, E., AND I. HAahtela. 1966. Habitat preferences and interspersion of species within the superspecies Jaera albifrons Leach (Crustacea, Isopoda). J. Anim. Ecol., 35:209-216.

NAYlor, E., AND I. HaAhtela. 1967. Quantitative ecological distribution of the Jaera albifrons group of species in the Baltic. Ophelia, 4:19-27.

Pethon, P. 1967-68. A note on the Jaera albifrons group of species (Isopoda Asellota) in Oslofjord. Nytt. Mzg. Zool. Norge, 15:118-123.

Prager, E. M., AND A. C. Wilson. 1975. Slow evolutionary loss of the potential for interspecific hybridization in birds: a manifestation of slow regulatory evolution. Proc. Natl. Acad. Sci., 72:200-204.

Prunus, G. 1968. Etude de systématique des populations chez l'Isopode Jaera (albifrons) albifrons Forsman. Arch. Zool. exp. gén., 109:643702.

Riley, H. P. 1952. Ecological barriers. Amer. Nat., $86: 23-32$.

RubinofF, R. W., AND I. RuBINOFF. 1971. Geographic and reproductive isolation in Atlantic and Pacific populations of Panamian Bathygobius. Evolution, 25:88-97.

SJöBERG, B. 1969. Population studies of the Jaera albifrons group. Limnologica, 7:69-73.

Solignac, M. 1967. Etude d'une forme nouvelle, paucahirsuta, de l'espèce Jaera (albifrons) praehirsuta (Isopodes Asellotes). Arch. Zool. exp. gén., 108:139-154.

Solignac, M. 1969. Hybridation introgressive dans la population complexe des Jaera albifrons de Luc sur Mer. Arch. Zool. exp. gén., 110:629652.

SolignaC, M. 1975. Isolement reproductif entre les membres de la superespèce de l'Isopode littoral Jaera albifrons Leach. Pubbl. Staz. Zool. Napoli, 39, suppl.:696-716.

SolignaC, M. 1976. Demographic aspects of interspecific hybridization. A study of the Jaera albifrons species complex (Crustacea, Isopoda, Asellota). Oecologia, 26:33-52.

Solignac, M. 1978a. Nature, déterminisme et origine des mécanismes d'isolement dans le complexe Jaera albifrons (Isopodes, Asellotes). Thèse, Université de Paris VI, 232 pp.

Solignac, M. 1978b. Genetics of ethological isolating mechanisms in the species complex Jaera albifrons (Crustacea, Isopoda). Pp. 637-665, in Marine Organisms: Genetics, Ecology and Evolution (J. A. Beardmore, and B. Battaglia, eds.). Plenum Publ., New York, 757 pp.

SolignaC, M. 1979. Analyse expérimentale et variabilité de l'hybridation interspécifique dans 
le complexe d'espèces affines Jaera albifrons (Crustacé Isopode). Arch. Zool. exp. gén., 120:353378.

STAIGER, H. R., ANd C. BocQueT. 1956. Les chromosomes de la super-espèce Jaera marina (F.) et de quelques autres Janiridae (Isopodes Asellotes). Bull. Biol. Fr, Belg., 90:1-32.

STALKER, H. D. 1942. Sexual isolation studies in the species complex Drosophila virilis. Genetics, $27: 238-257$.

Thoday, J. M. 1972. Disruptive selection. Proc. R. Soc. London B, 182:109-143.

Udovic, D. 1980. Frequency-dependant selection, disruptive selection, and the evolution of reproductive isolation. Amer. Nat, 116:621-641.

VEUILLE, M. 1976. Biogeography of the Jaera albifrons superspecies (Isopoda, Asellota) on the Atlantic coast of Canada. Can. J. Zool., 54:12351241.

VEuILLE, M. 1979. L’évolution du genre Jaera et ses rapports avec l'histoire de la Méditerranée. Bijd. tot. de Dierkunde, 49:195-217.

Watanabe, T. K., AND M. Kawanishi. 1979. Mating preference and the direction of evolution in Drosophila. Science, 205:906-907.

WHITE, M. J. D. 1978a. Modes of Speciation. Freeman and Company, San Franciseo, $455 \mathrm{pp}$.

White, M. J. D. 1978b. Chain processes in chromosomal speciation. Syst. Zool., 27:285-298.

Wilson, A. C., L. R. Maxson, and V. M. Sarich. 1974. Two types of molecular evolution. Evidence from studies in interspecific hybridization. Proc. Acad. Natl. Sci., 71:2843-2847.

Wilson, E. O. 1965. The challenge from related species. Pp. 7-27, in The Genetics of Colonizing Species (H. G. Baker, and G. C. Stebbins, eds.), Academic Press, New York, 588 pp.

Manuscript received June 1980 Revised April 1981 